\title{
Teaching reading strategies in ELT
}

\section{Gulmira AHMADALIYEVA ${ }^{1}$}

Fergana State University

\begin{tabular}{l} 
ARTICLE INFO \\
\hline Article history: \\
Received April 2021 \\
Received in revised form \\
20 April 2021 \\
Accepted 15 May 2021 \\
Available online \\
25 June 2021 \\
\hline
\end{tabular}

\section{Keywords:}

reading strategies, reading comprehension, learning techniques, classification of strategies, learning process.

\begin{abstract}
The term "strategy" can be applied to the behavior of a learner in a foreign language environment, which directly affects his learning - what the student does to control or transform the information received in a foreign language and regulate his learning. Strategies for learning a foreign language are special actions or techniques that are always problem-oriented, that is, students use them when the need arises, for example, to read and understand a foreign language text. Reading includes the skills and abilities associated with the possession of linguistic material (reading comprehension, guessing), as well as the ability to understand (extract) the information contained in the text for meaningful reading. This article discusses reading strategies in teaching English.
\end{abstract}

2181-1415/C) 2021 in Science LLC.

This is an open access article under the Attribution 4.0 International (CC BY 4.0) license (https://creativecommons.org/licenses/by/4.0/deed.ru)

\section{Ingliz tilini o'qitishda o'qish strategiyalarini o'rgatish}

Kalit so'zlar:
o'qish strategiyalari,
o'qishni tushunish,
o'rganish texnikasi,
strategiyalarni tasnifi,
o'quv jarayoni.

ANNOTATSIYA

"Strategiya" atamasi o'quvchining chet tili muhitidagi xattiharakatlariga bog'liq bo'lib, uni chet tilida o'rgangan ma'lumotini boshqarishi yoki o'zgartirishi va o'rganishini tartibga solishiga bevosita ta'sir qiladi. Chet tilini o'rganish strategiyasi bu - har doim muammoli bo'lib turadigan maxsus harakatlar yoki uslublar, ya'ni talabalar ulardan zarurat tug'ilganda, masalan, chet tilidagi matnni o'qish va tushunish uchun foydalanadilar. O'qish orqali lingvistik materialni egallashi (matnni tushunish, taxmin qilish) bilan bog'liq bo'lgan bilim va ko'nikmalarni, shuningdek o'qish uchun matndagi ma'lumotlarni tushunish (ajratib olish) qobiliyatini o'z ichiga oladi. Mazkur maqolada ingliz tilini o'qitishda o'qish strategiyalari muhokama qilinadi.

\footnotetext{
${ }^{1}$ EFL lecturer, Fergana State University. Fergana, Uzbekistan

E-mail: Gulmira2021@gmail.com.
} 


\section{Обучение стратегиям чтения при обучении английскому языку}

\author{
Ключевые слова: \\ стратегии чтения, \\ понимание прочитанного, \\ методы обучения, \\ классификация стратегий, \\ процесс обучения.
}

\begin{abstract}
АННОТАЦИЯ
Термин «стратегия» может быть применен к поведению учащегося в иностранной языковой среде, которое напрямую влияет на его обучение - что студент делает, чтобы контролировать или преобразовывать информацию, полученную на иностранном языке, и регулировать свое обучение. Стратегии изучения иностранного языка - это особые действия или приемы, которые всегда проблемноориентированы, то есть учащиеся используют их, когда возникает необходимость, например, чтобы прочитать и понять текст на иностранном языке. Чтение включает в себя навыки и способности, связанные с владением лингвистическим материалом (понимание прочитанного, угадывание), а также способность понимать (извлекать) информацию, содержащуюся в тексте, для осмысленного чтения. В этой статье обсуждаются стратегии чтения при обучении английскому языку.
\end{abstract}

Teaching reading in ELT has been one of the actual issues and the methods and techniques of teaching foreign language reading strategies became the subject of our research interest. Some researches reveal that the students used a variety of reading strategies and approaches. In the first stages of learning, students use a dictionary when reading, try to memorize or memorize words, take notes and translate word by word. At a later stage of training, having the necessary skills and abilities, they guess the meanings of the words contained in the text from the context. In the final stages, students use strategies such as "applying transition words", "looking for clues in the text" and using accumulated and background knowledge. When teaching to read, reading skills are often confused with strategies. Reading skill is defined as a tool a student uses to improve his or her reading ability.

The reading strategies can be broken down into seven areas:

1. Forecasting - prediction based on observations and / or personal experience.

2. Visualization - the formation of mental images of scenes, characters and events.

3. Linking - linking two or more things together or seeing a link while reading a text.

4. Question - asking or considering.

5. Clarification - to make it comprehensible or to be clear and free from confusion.

6. Summation - concisely define the essence of the text.

7. Evaluation - to form an opinion about the read [1].

To develop the skills of reading text in English, linguists offer the teacher the following strategy - to teach students to focus on the text itself, and not on the sentences in it. To understand most of what you read, you must learn to understand the structure of such long units, such as a paragraph or the entire text.

- focus on reading skills and learning strategies and plan comprehension exercises for each;

- you should not impose your own interpretation on students. They should be taught to think by providing enough evidence for them to follow the correct path; 
- should not be superimposed on the text of the exercise. You don't have to use a lot of exercise to ruin your reading pleasure.

- help students to increase their reading speed.

- it is necessary to use different procedures when guiding the student's reading. Self-correcting exercises are extremely beneficial [2].

There are many strategies for teaching reading. Most scientists identify the following:

$>$ challenge the corresponding basic knowledge;

$>$ predicting what will be learned and what will happen;

$>$ creating mental images;

$>$ self-control and self-correction;

$>$ using corrective strategies such as rereading or seeking help;

$>$ identifying the most important ideas and events and observing how they are related;

$>$ the ability to draw conclusions, substantiate your opinion;

$>$ compare and contrast what has been read and background knowledge, find out unknown words, summarize what has been read [1].

One of the most important prerequisites for reading is background knowledge. Scholars argue that knowledge is an essential component of reading comprehension. Various studies have shown that the amount of a reader's prior knowledge can be a very strong determinant of how well the reader can understand the text being read. The accumulated knowledge helps learners to interpret reading materials personally, on an individual basis. Thus, it is imperative that teachers teach students how to use their own basic knowledge when reading a text as a strategy for its text. A student with strong background knowledge will have a better ability to understand and represent what the author is trying to portray in the text. Thus, it can be argued that a strong prior knowledge base greatly influences how well the reader will understand the text. When students make predictions, they decide their reading goals. Text prediction works closely with background knowledge. Using their background knowledge, students figure out or predict what will happen next. In addition, they make predictions before reading, relying on basic knowledge first. By applying this strategy, students are able to integrate what they know while reading, as well as are faced with new information that may contradict their own assumptions, which, in turn, can strengthen critical thinking skills [3].

The strategies outlined above for teaching reading can be applied to teaching reading in English. Linguists have developed many reasonably effective methods of teaching reading that teachers can use and use to motivate students to focus on one or more reading strategies can be easily applied in the lesson.

I. Procedural prompts.

Procedural prompts can be used to help students generate questions and summarize what they have read. Linguists argue that this should be the first step in teaching students' cognitive strategies. It is the procedural prompts that serve to develop the basic knowledge of students and provide support for knowledge, which they can apply. For example, to formulate questions about the narrative text, teachers recommend that teachers and students give or formulate clues that are based on the grammar of the text itself:

- Who are the main characters?

- What problem did the main character face? 
- What attempts were made to solve the problem?

- How was the problem finally resolved?

- What is the theme of the story? [2].

II. Discussion of the text.

In order to teach students to use different reading strategies, teachers should use "activities" such as discussion to encourage students to relate the topic of the text to their own experience. Since learners of reading cannot retell or relate all the events that occur in the text, teachers should help students understand the meaning of the text being read using their own background knowledge. An effective way to encourage students to turn to background knowledge is to engage them in a discussion before reading. In 1996, scholars explored ways to use informational text through discussion. They looked at research from experienced readers who analyzed conversations about themselves before, during, and after reading. It was found that these readers have the ability to better comprehend ideas in the text, make predictions and hypotheses using previously gained knowledge, and are able to critically evaluate what they read. First, individual students silently read the highlighted text. They are then given four value statements that are relevant to reading choices and possibly controversial. They are then asked to write down how other members of the group will react. Finally, students are regrouped to compare predictions and should challenge and support each other's answers by supporting arguments using textual information and prior knowledge. In addition, this exercise allows students to monitor their understanding and check the accuracy of their predictions [3].

Scientists distinguish the following types of reading:

Reading. This kind of reading can be defined as a "skimming" and scanning activity. For others, it is the amount of material read.

Home reading. In this type of activity, the teacher selects material for reading, then this material is read by students at home.

Extensive reading. This type of reading is an individual student's lesson, which can be not only in the classroom, but also at home. In this activity, students may be allowed to independently select reading materials based on their interests and language level.

Intensive reading. This type of reading is associated with short texts used by students to learn the language. They are used in the study of lexical, syntactic or discursive aspects of the studied languages [1].

\section{REFERENCES:}

1. Birkner V. Reading Comprehension in Teaching English as a Foreign Language: https://www.monografias.com/trabajos68/readins-comprehension-teaching-english/ readins-compre-hension-teaching-english2.shtml.

2. Peacock M. (1997) The Effect of Authentic Materials on the Motivation of EFL Learners in English Language Teaching Journal 51

3. Nuttall C. (1996) Teaching Reading Skills in a foreign language (New Edition) Oxford, Heinemann

4. Wallace C. (1992) Reading Oxford, O.U.P.

5. Sarimsakova D. (2021). Developing the sociolinguistic competence of future English teachers through the use of case studies. Mental Enlightenment ScientificMethodological Journal, 2021(2). - PP. 54-65. 
6. Sarimsakova D.M. (2021). Using interactive board "padlet" to develop sociolinguistic competence of future english teachers in controlled independent education.

7. Dildora, Jabborova., \& Miravaz M. Common Techniques in Teaching of Reading. International Journal on Integrated Education, 3(1). - PP. 65-68.

8. Dildora, Jabborova. (2019). Promoting extensive reading in efl classroom. European Journal of Research and Reflection in Educational Sciences Vol, 7(11).

9. Саримсакова Д. (2020). The importance of the use of distance education in the development of sociolinguistic competence of future english teachers. Scientific Bulletin of Namangan State University, 2(7). - PP. 460-465. 